\title{
What do people think about the flood risk? An experience with the residents of Talcahuano city, Chile
}

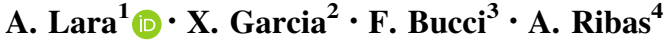

Received: 30 September 2015/Accepted: 25 October 2016/Published online: 18 November 2016

(C) The Author(s) 2016. This article is published with open access at Springerlink.com

\begin{abstract}
In the province of Concepción (Chile), floods are considered one of the main natural hazards. One of the most important cities of this area is Talcahuano. During the last years, Talcahuano has been affected by a number of flood episodes, as a consequence of an increase in the frequency of extraordinary atmospheric events, along with a higher exposure to the flood risk caused by an intense urban development. On 27 February 2010, an $8.8^{\circ}$ earthquake (Richter scale) occurred in central southern Chile and originated the tsunami which flooded a large percentage of the residential area and military base of the Talcahuano city. This flood event affected a population higher than 180,000 people (including 23 casualties and invaluable economic and environmental losses). The objective of this study is to investigate the social perception and knowledge of Talcahuano residents affected by different types of flood, including tsunami, emphasizing which are their risks, vulnerability, resilience and coping capacity concepts. In addition, the kind of measures that have been proposed to improve their capacity to face floods after having suffered the natural disaster will be determined. This social assessment has been carried out based on a survey to permanent residents. Research results reveal that their endogenous and exogenous characteristics have resulted determinant to explain their perception.
\end{abstract}

Keywords Flood $\cdot$ Risk management $\cdot$ Public participation $\cdot$ Social learning

A. Lara

alejandrolara@udec.cl

1 Department of Architecture, University of Concepción, Barrio Universitario S/N, Concepción, Chile

2 School of Architecture, International University of Catalonia, Inmaculada 22, Barcelona, Spain

3 MSc in Urban Environmental Management Program, Wageningen University and Research, Droevendaalsesteg 4, 6708 PB Wageningen, The Netherlands

4 Department of Geography, University of Girona, Plaça Sant Domènec, 3 Edifici Les Àligues, 17071 Girona, Spain 


\section{Introduction}

Over the past two decades, it has been repeatedly demonstrated that "top-down" approaches have ignored aspects such as roles, capabilities, vulnerabilities and needs of the community with regard to disaster risk reduction (WMO 2008). Today, under a prevailing crisis of political systems, society feels frustrated because it has been excluded from risk management and planning of decision-making processes at community level (Rubin 1991). Hence, if the local authorities responsible for security and risk management ignore the local community, the likelihood of success may decrease (Pearce 2003) due to the lack of involvement of the target population in the process. In response to the limitations of the "top-down" approaches, an alternative approach emerged during the 1980s and 1990s, which supports disaster management at local community level (Tanahashi 2005).

On the other hand, the scientific community, especially during the last decade, has focused its attention on improving natural hazards management, incorporating a social component. These multidisciplinary studies have ranged from topics such as: identification of factors that influence the decision of the community to cooperate in disaster management (Brilly and Polic 2005; Howgate and Kenyon 2009; Lara et al. 2010; Martin 2010; Das 2011); development of social resilience capacity (Bahadur et al. 2010; Norris 2011; Sok et al. 2011; Ashley et al. 2012; Bakker et al. 2012); or aspects of uncertainty linked to climate change, where participatory approaches with different stakeholders are working together to develop a common strategy by managing water resources and urbanization (Ribarova et al. 2011; Burch et al. 2010; White et al. 2010; Samuels et al. 2010; Lomas and Giridharan 2011). These studies have contributed to the development of government approaches that lead to the implementation of participatory and inclusive public policies.

Although creating a risk culture might be considered by some residents as a government responsibility, it responds to a shared responsibility among the stakeholders. For example in South and Southeast Asia, governments have promoted the creation of flood management committees at community level, clearly defining their structure, roles and responsibilities before, during and after flooding events (Prasad 2005). In Cuttack, India, the risk assessment process has been carried out jointly by the government and the community. This cooperation, which was started over two decades ago, has enabled community-led data collection and mapping. Nowadays, the mapping includes areas determined by GPS and maps of informal urban settlements. That made it possible to create an accurate and disaggregated database of vulnerability and risk boundaries, which is used to carry out risk assessments for the whole city (Livengood and Kunte 2011). In the Philippines, urban communities have participated in the identification and prioritization of post-disaster aid, as well as the management and monitoring of the supplies delivered to homes and for other purposes. In addition, community associations have used their own savings to put pressure on the municipal government and get additional funding in order to secure land for housing after a disaster (Carcellar 2011). Before European settlement, Native Americans who lived near the rivers of the Snohomish County (USA) were affected by flooding events. Thus, the first farming and non-farming settlers who established themselves on the banks had to learn to live with this problem. Since the early 1900s, the federal government in Washington engaged these settlers in the processes of constructing dams and dikes to cope with the effects of flooding. This partnership (federal-county government) noticed its maximum benefit for residents in flood areas in 1984, when the county was incorporated into the National Flood Insurance Program (NFIP). This federal programme is administered by the Federal Emergency Management Agency (FEMA) of the USA. It has allowed homeowners 
and counties that have adopted the ordinance on the ban on building in flood plains, access to affordable insurance to protect their property from the negative flood effects. In addition, local communities in southern France, which are faced with the continued increase in flood risk, have been forced to take on the mission of protecting and informing the public in relation to flooding and its management. The experience of those affected has become a valuable tool. Since 2003, the PREDICT-Services initiative has developed a flood management project that takes the local community into account. Its aim is to help communities and companies to tackle flood risk and promote social awareness of this problem. Together, they have prepared emergency and security plans which are under ongoing evaluation in order to effectively reduce the level of risk (Moreau and Roumagnac 2009).

Both participation and community involvement in the management of risks will reveal a number of distinctive local processes (Terpstra and Gutteling 2008; Schaich 2009). These include a greater awareness of losses, impacts and disaster risks at the local level (Perwais 2011). It will also encourage building partnerships with local governments and other stakeholders, to enable the negotiation of priorities, public investment and aid (Mitchell et al. 2012). In addition, it will help with the implementation of measures that not only reduce the risk of disasters, but provide additional benefits such as improvements in local infrastructure and services (Maskrey 1989, 2011; Satterthwaite 2011). In conclusion, people should be invited and encouraged to participate in the formulation, design and implementation of local public policies that incorporate management and risk reduction. On the other hand, this novel management option requires significant changes that relate to social risk perception and attitudes towards natural hazards. Hence, the need to change individual perceptions of risk through the active participation of residents in order to link them to the management of local development becomes a key issue in increasing disaster management through social learning.

The aim of this article is to analyse the social perception of flood risk and the social assessment regarding flood management effectiveness, by residents of Talcahuano, Chile, considering their recent experience with the earthquake-tsunami that took place on 27 February 2010. Emphasizing which are their risk vulnerability and coping capacity concepts as well as the kind of measures they proposed to reduce their flood vulnerability is also a key aspect of the study. This is a pioneering study on this topic due to one major reason; the land planning process and the measures to attend to an emergency situation are unprecedented in this case study, let alone the public participation for improving the management of natural hazards.

The work is organized as follows: after the present introduction, Sect. 2 presents the study area. In Sect. 3, the method for the collection of data on social perception and assessment of flood management is explained. Section 4 is dedicated to data analyses of results; Sect. 5 develops the discussion of results, whereas Sect. 6 offers some conclusions and ways in which we could contribute with new skills and knowledge of interest to decision makers while developing and implementing a local strategy for disaster risk reduction.

\section{Case study}

Talcahuano or tralkaweñu, which in Mapudungun language means "thundering sky", is a municipality in south-central Chile (171,463 inhabitants in 2012) (Fig. 1). It belongs to the province of Concepción and, in turn, to the Biobío Region, and, together with six other 


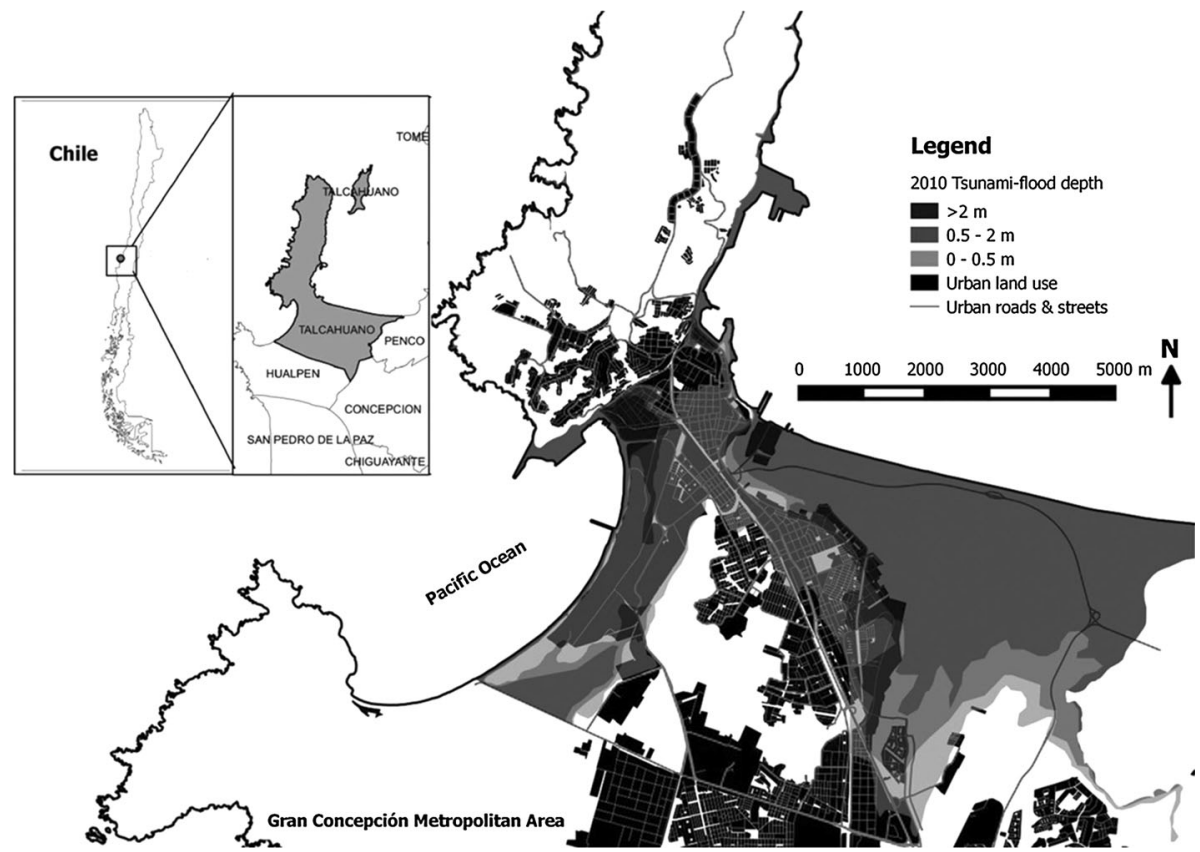

Fig. 1 Situation map of Talcahuano city and the effects of the 2010 earthquake-tsunami. Source: based on data from the Municipal Secretariat for Planning (SECPLAN), Municipality of Talcahuano

municipalities, it makes up the metropolitan area called Gran Concepción (700,000 inhabitants in 2014). Located facing the Pacific Ocean, Talcahuano is recognized as one of the biggest port cities of Chile. It has three ports: Huachipato, Talcahuano and San Vicente. The main economic activities are related to the port, such as storage, transportation and logistics services, as well as an important ensemble of industries linked to fishing, steel, petrochemicals, cement and gas.

Talcahuano has a temperate climate with a dry season that may be extended over 4-5 months. Even though occasional summer precipitations occur, most of the rainfall is distributed between May and August, coinciding with the end of the autumn season and the beginning of the winter season, reaching on average $206.8 \mathrm{~mm}$ in June (DMC 2008). Its average annual temperature is $11^{\circ} \mathrm{C}$. In February, the warmest month of the year, the average maximum daily temperature is $22{ }^{\circ} \mathrm{C}$, and the minimum is $10{ }^{\circ} \mathrm{C}$. Geomorphologically, Talcahuano is a lowland isthmus that connects a mountainous plateau, the Tumbes Peninsula, with the mainland. It lies at an altitude of $1 \mathrm{~m}$ above sea level. From the lithological point of view, the area consists of a basement of crystalline rocks: Palaeozoic granites and Precambrian slates. The Andalién River is the main river that crosses the city and forms the natural boundary with the city of Concepción (basin area of $780 \mathrm{~km}^{2}$ and a length of $130 \mathrm{~km}$ ). Other minor water courses, of exoreic character, are present in the city, such as Ifarle, El Morro and Patos channels, which flow through the city area from the south-east to the north-west.

Due to its geographical location, Talcahuano is a city exposed to various natural hazards. Floods are not an isolated phenomenon, but rather a continuous and evolving issue. According to Alarcón (1995), just in the decade of the 1980s, Talcahuano suffered five important episodes of flooding, where extreme frontal systems had a major role. In June 
1982, twenty families were affected in Las Salinas neighbourhood by the overflowing of Andalién River. Then, in March 1985, there was a sea flooding that affected a fishing cove called El Morro. Also, in July 1988, 974 people were affected in Santa Clara by the overflowing of Andalién River. In July of the same year, there was another flood that completely inundated Las Higueras neighbourhood.

The beginning of the twenty-first century was no different. The Chilean Emergency Office (ONEMI in Spanish) reported that in June 2003 a frontal system flooded and affected 25 people and 5 houses were damaged. In May 2005, another frontal system caused 460 disaster victims, and a total of 20,300 houses were damaged. Finally, the frontal system of July 2006 caused one of the biggest flood emergencies in Chile. In Talcahuano alone, floods caused more than 5800 disaster victims and 1300 damaged houses and disrupted school activities for an entire month. According to Mardones and Rojas (2012), in the last decade, frontal systems have contributed to the overflow of Ifarle and El Morro channels, which have become the most common cause of flooding in the neighbourhoods of the city port.

However, extreme climatic events are not the only cause of flood risk, since the existence of an improperly maintained or badly planned urban drainage system contributes to increase this risk. Human occupation of floodplains, sometimes outside building regulatory frameworks, has become one of the main factors contributing to increased risk of flooding in the area. The urban expansion that begun in the 1980s had the Communal Regulatory Plan of 2005 as an antecedent that tended to encourage building throughout the urban area through the excessive easing of land uses, within each one of the sectors of Talcahuano (Municipality of Talcahuano 2006). Definitely, the necessity to attract real estate investments to the city meant that the local administration relaxed the formal requirements for urbanization, enabling the building of new neighbourhoods with insufficient or inexistent sewage systems and qualifying the entire urban limits of the city as an area exposed to flood risk, according to the regional office of emergencies.

As expected, floods have been present in the last few years. One of the most recent examples was the flood event that lasted from 10 July 2006 to 13 July 2006, which was caused by a rainfall event that reached over $182.6 \mathrm{~mm}$, affecting 5886 residents, 7 of them casualties and 788 damaged, destroying 42 houses and damaging 1133 more (ONEMI 2006). Two years later (24 August 2008 to 1 September 2008), another frontal system event caused a rainfall event of $154 \mathrm{~mm}$, flooding homes with water levels of $30 \mathrm{~cm}$, damaging walls and furniture (ONEMI 2008). Also, on 27 February 2010, an earthquake of 8.8 on the Richter scale hit south-central Chile, generating a tsunami that swept the coasts of the country, including the city of Talcahuano (ONEMI 2012). The tsunami flooded a large percentage of the residential area and the military base and affected more than 180,000 people, including 23 casualties, 1805 displaced, 56,535 injured, 6600 houses and 24 schools destroyed and invaluable economic and environmental losses.

Beyond the tsunami and its impacts, flood is not an isolated issue. Flood episodes related to extreme rainfall events of 1988 and 2006 were as harmful as the 2010 flood caused by the tsunami. Floods are produced by extreme events, which reflect the vulnerability of human settlements and infrastructure of the city in coping with the risk of flooding (see Fig. 1).

In summary, the city of Talcahuano is considered an interesting case study to be analysed, based on four factors: firstly, its geomorphological characteristics, representing an area highly exposed to the risks of urban flooding because it is primarily located on a lowland plateau, whose central area is hardly at 1 m.a.s.l; secondly, its importance for national economic development, being the second-largest port in Chile and the most 
important in the south, meaning that any disaster that occurs in the territory affects the economic activities not only at the community level, but also at the regional and national levels; thirdly, its importance to national defence and logistics, because Talcahuano, specifically the Tumbes plateau, is the location of the Second Navy Zone; finally, an economic model with a strong presence of the real estate sector that has been implemented in the area, which has developed urban land uses and increased the population density in flood-prone areas, increasing the exposure of residents to flood risks.

\section{Materials and methods}

The remarkable methodological characteristic of this research is the fact that it applied a combination of qualitative and quantitative methodology. Based on the type of data and analysis methods, we chose this mixed methodological approach to investigate the social perception towards flood risk reduction, as it allows for comparison, measurements and the transfer of results about perception through analysis and observation (González 1997). The research design is considered a case study because it refers to a defined object of study, which makes sense as an entity within the context, which is considered relevant to be studied (Pérez 2001).

This research paper used a perception survey as a data collection technique to obtain, in a systematic and orderly manner, information about what people do, think, feel, hope, wish for, want or hate, approve or disapprove of, or the reasons for their actions, opinions and attitudes (Sierra 1985). The survey used in this study, and according to the criteria identified to categorize this instrument (Visauta 1989), is descriptive, personal, of fact and opinion, and of synchronous character. It is descriptive because it is aimed at determining what the perception is of the residents of the city of Talcahuano towards the risk of flooding. It is personal because responses were obtained through a questionnaire designed and implemented as a face-to-face survey at the houses of people and at transitional emergency housing where they were dwelling, by four interviewers who had been previously trained for this purpose, besides being residents of the same city. Regarding its content, and following Javeau (1971), it is about facts because respondents are the main protagonists in relation with the information to be collected, in this case because of their socio-demographic characteristics (based on locations subject to flooding), and of opinion since the responses of the residents are verbal statements expressing subjective perceptions. Finally, in relation to the temporal dimension, the survey is synchronous because it seeks to obtain results at a certain time (14 months after the tsunami).

For the purposes of the survey, it was considered that the study population, according to the objectives of the research, should consist of residents living in areas exposed to floods in the city of Talcahuano. The total population located in the flood-prone areas of the city was estimated based on the 2002 national census, updated by the district records of parliamentary and presidential elections of 2009, and the municipality records. We considered the total estimated population of residents in flood-prone areas, which amounted to 28,826 people in 2009.

To calculate the sample, a formula presented by Sierra (2001) was used, which stipulates that the sample size should be a proportion of the universe with a minimum size established by statistical criteria, set according to experimental laws of probability. Concretely, the equation used is: 
Table 1 Total population estimated espoused to flood risk and sample by flood-prone Talcahuano neighbourhood

\begin{tabular}{lccc}
\hline Neighbourhood & \multicolumn{2}{c}{ Population exposed } & \multirow{2}{*}{ Sample } \\
\cline { 2 - 3 } & Count & $\%$ & Count \\
\hline Santa Clara & 3.352 & 11.6 & 47 \\
Las Salinas & 3.821 & 13.3 & 53 \\
Tacahuano Centro & 2.197 & 7.6 & 30 \\
Caleta Tumbes & 1.407 & 4.9 & 20 \\
Las Higueras & 4.721 & 16.4 & 66 \\
Los Condores & 2.255 & 7.8 & 31 \\
Las Canchas & 5.784 & 20.1 & 80 \\
Denavi Sur & 5.289 & 18.3 & 73 \\
Total & 28.826 & 100 & 400 \\
\hline
\end{tabular}

$$
n=\frac{4 \cdot N \cdot p \cdot q}{E^{2}(N-1)+4 \cdot p \cdot q}
$$

where $n=$ sample size (number of individuals); $N=$ population size or universe (number of individuals); $E=$ margin of tolerated error $(\% * 0.01) ; p=$ proportion of the variable in the population $(\% \times 0.01) ; q=1-p$.

Regarding the heterogeneity of the sample universe, it was defined at $50 \%$, while the margin of error was set at 5\%, and the confidence level at $95 \%$. The statistical formula determined a minimum sample size of 396 individuals; however, we expanded it to 400, in order to ensure the representativeness of the sample. To ensure proportional sampling, the area exposed to flooding was divided into four sectors, including two neighbourhoods per sector. Therefore, the number of surveys conducted in each of the selected neighbourhoods was proportional to their population (Table 1 and Fig. 2).

The surveys were carried out from April to July 2011. From a total of 440 people consulted, only 40 refused to participate in the study. The main reason for declining was the traumatic effects of the earthquake-tsunami event and their declared desire to overcome these. The questionnaire design ensured that the first questions were simple and potentiated the interest of the respondents, leaving the most compromising questions at the end. An English version of the questionnaire can be found in Supplementary Information section. The questions were grouped into six categories: (1) experience with the risk; (2) vulnerability; (3) coping capacity; (4) resilience; (5) adaptation to risk; and (6) sociodemographic characteristics.

The representativeness of the survey response is also supported by some socio-demographic characteristics of the sample, as shown in Table 2. The average age of respondents was 47 years, half of them (50\%) had completed at least secondary school, and $24 \%$ had a higher degree. ${ }^{1}$ Also, most of the respondents were living in an owner-occupied home $(69 \%)$. It is worth noting that the proportion of female respondents was higher $(66.75 \%)$ than that of male counterpart (33.25\%). An explanation for this could be because women were more often at home during the time the surveys were conducted, and had a greater willingness to participate. Regarding their housing damage, $5.5 \%$ claimed to have suffered

\footnotetext{
${ }^{1}$ For this research, higher degree considers post-secondary studies, which means technical education, university and postgraduate studies.
} 


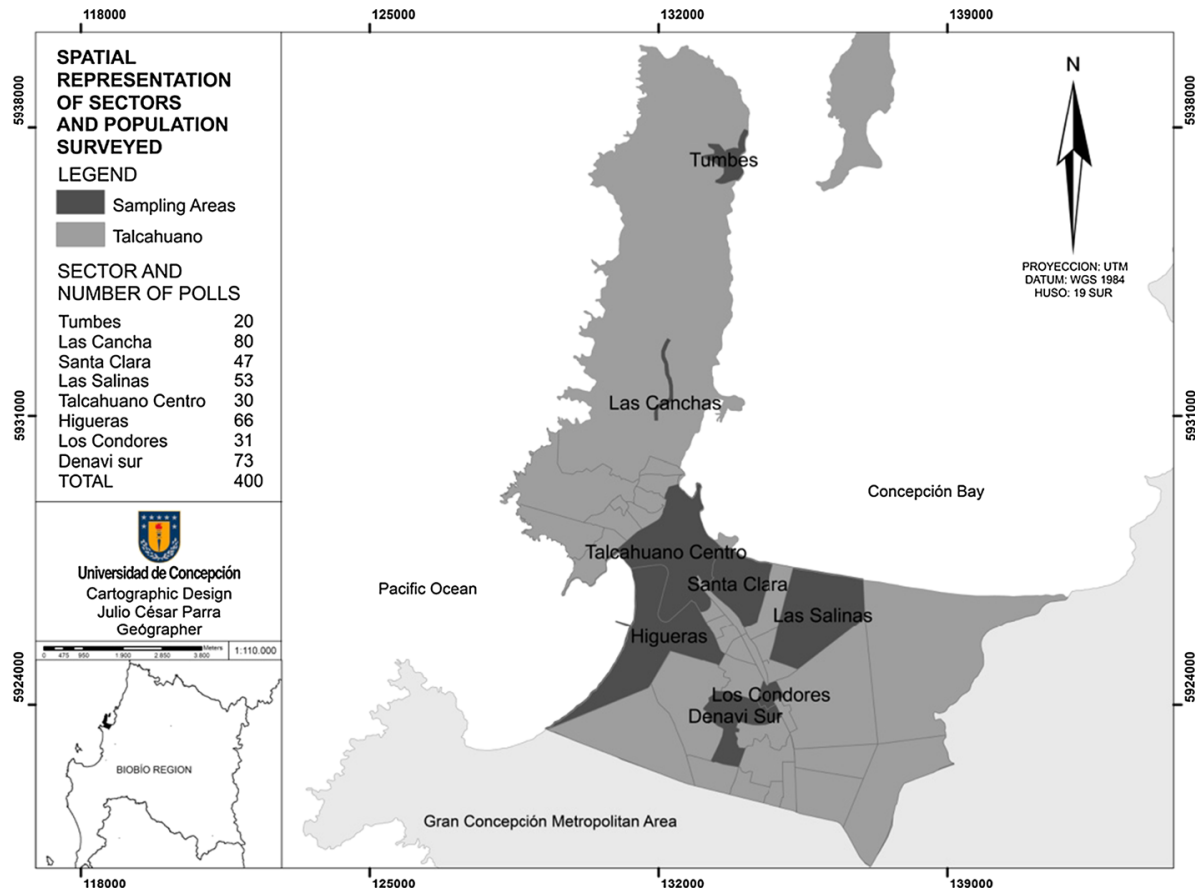

Fig. 2 Spatial representation of sector and population surveyed. Source: based on data from the Municipal Secretariat for Planning (SECPLAN), Municipality of Talcahuano

Table 2 Socio-demographic characteristics of the sample

${ }^{\text {a }}$ This part shows the results of the question in the questionnaire "Was your home affected by the $27 \mathrm{M}$ earthquake-tsunami episode?"

\begin{tabular}{llll}
\hline Characteristic & Category & Count & $\%$ \\
\hline Gender & Male & 133 & 33.25 \\
& Female & 267 & 66.75 \\
Age & Avg. (SD) & $47.42(14.88)$ & - \\
Education level & No schooling & 8 & 2 \\
& Primary education & 95 & 23.75 \\
& Secondary education & 200 & 50 \\
& Higher education & 97 & 24.25 \\
Housing typology & Owner-occupied home & 276 & 69 \\
& Rental housing & 60 & 15 \\
& Other options & 64 & 16 \\
Damage $^{\text {a }}$ & No damage & 73 & 18.25 \\
& Earthquake & 193 & 48.25 \\
& Tsunami & 22 & 5.5 \\
& Both & 112 & 28 \\
\hline
\end{tabular}

damage to their house due only to the tsunami, whereas $28 \%$ claimed both the tsunami and the earthquake of the 27 February event damaged their house.

Finally, quantitative assessment that allowed the comparison of the different perceptions of flood risk in Talcahuano was carried out using cross-tabulation, where the type of 
resident regarding their experience with floods is the independent variable. This variable was used to compare the results of perceptions of vulnerability, resilience, coping capacity, adaptation to flood risk and participation, considering the dependent variables, which explained the social perception of the risk of flooding in the city.

\section{Results}

\subsection{Risk perception}

Regarding risk perception, the issue of whether or not they were affected by some episodes suggests a trend among residents surveyed. The perception of risk is greater in the case of affected residents and makes the experience a determining factor in awareness, knowledge and understanding of the risk. When the residents of the city of Talcahuano were asked about their perception of being affected by some kind of risk, they expressed their inclination and certainty, not only towards a single hazard, as the conviction exists that earthquakes will be a recurring phenomenon. They also said that it is likely that these earthquakes will be capable of causing a tsunami; this perception was clearly influenced by the experience suffered following the earthquake-tsunami, on 27 February 2010 (Fig. 3). The second and third most prevalent perceived risks were floods, caused by either strong rainfall or a river overflow, reaching 35 responses in the case of affected residents and 46 responses from residents unaffected by this risk.

Now, if we look at future risk perception, that is, over the next 20 years (Fig. 4), experience of risks dominates the responses of the surveyed residents. Seventy-one per cent of residents affected by any flood episode, or other events, have very high (37\%) and high $(34 \%)$ perception that they will suffer negative effects from natural hazards. When comparing the same categories with non-flooded residents, this perception decreases for both, very high $(16 \%)$ and high $(32 \%)$, positioning the prevalence of risk perception at a medium level (38\%).

\subsection{Perception of management and coping capacity}

Knowing the level of resources and the way in which people and organizations can use these resources, tools and skills available to deal with a disaster corresponds to a fundamental part of the knowledge and perception present among residents regarding the risk. In addition, the opinion of residents towards the administration regarding how these situations are handled can help us not only to understand the closeness of government with the people, but also to improve the trust of institutions by them, and allows us to know, from the point of view or residents, the level of priority that the government gives to risk management and disaster reduction.

The resources available to face risk are vital to help reduce the negative effects that floods produce in a territory. Thus, residents surveyed in Talcahuano leaned towards a negative evaluation of the effectiveness of different levels of government in relation to the action developed for disaster risk reduction. This may explain why the fair and poor categories are predominant in the qualitative assessment (Figs. 5, 6). While residents mentioned that the event on 27 February 2010 responds to a sporadic fact, they indicated that their prevalence of flood risk is a historical problem that was compounded by the 


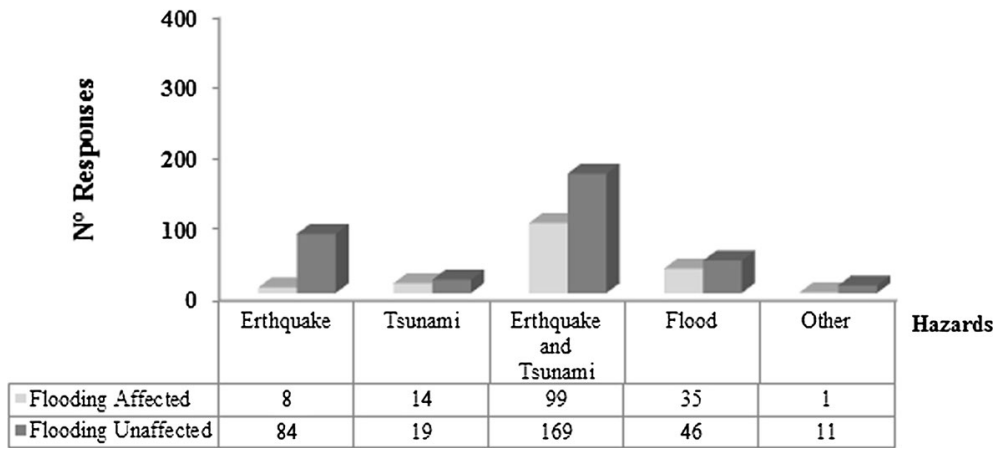

Fig. 3 Perception of being affected by some kind of natural hazard of citizens in flood-prone areas in Talcahuano

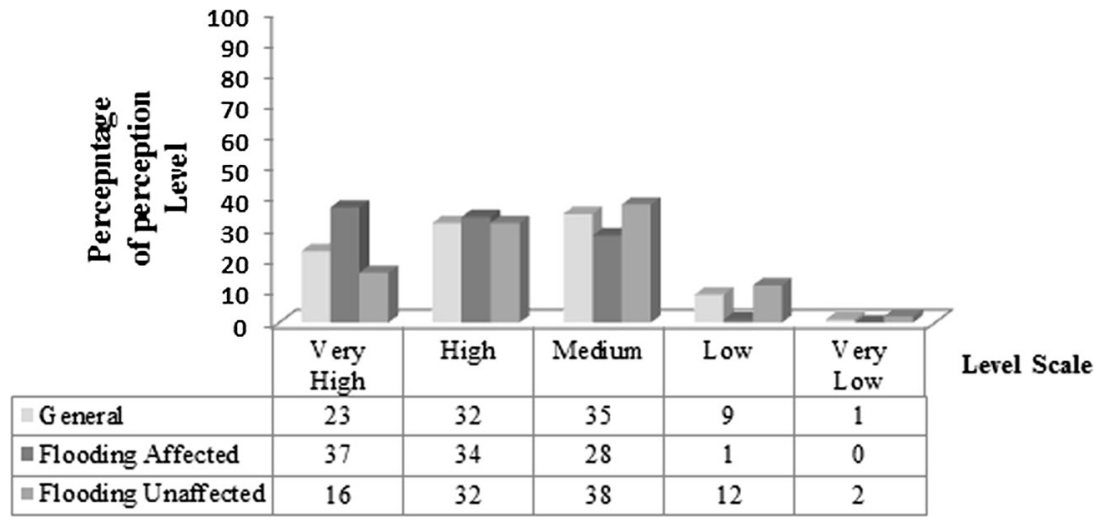

Fig. 4 Perception of future risk by natural hazards of citizens in flood-prone areas in Talcahuano (in percentage)

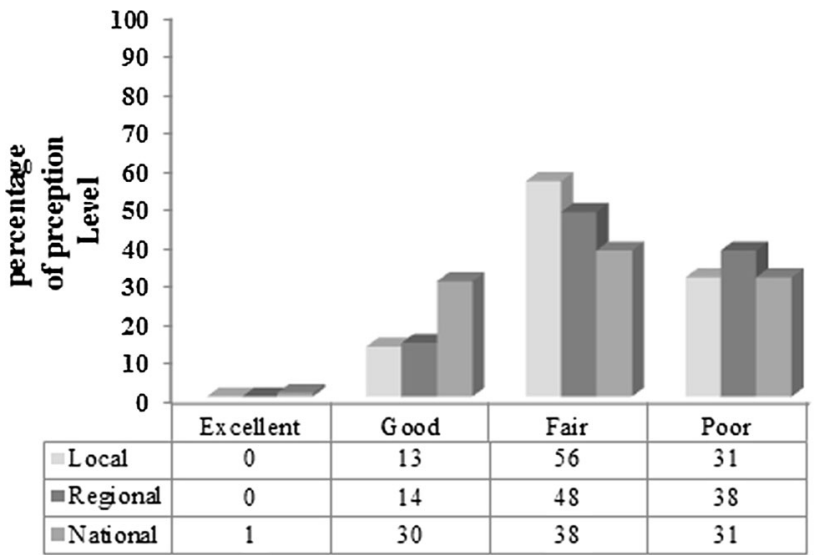

\section{Level Scale}

Fig. 5 Perception of flood risk management level of effectiveness of the different administrative levels of Chile by flooding affected residents 


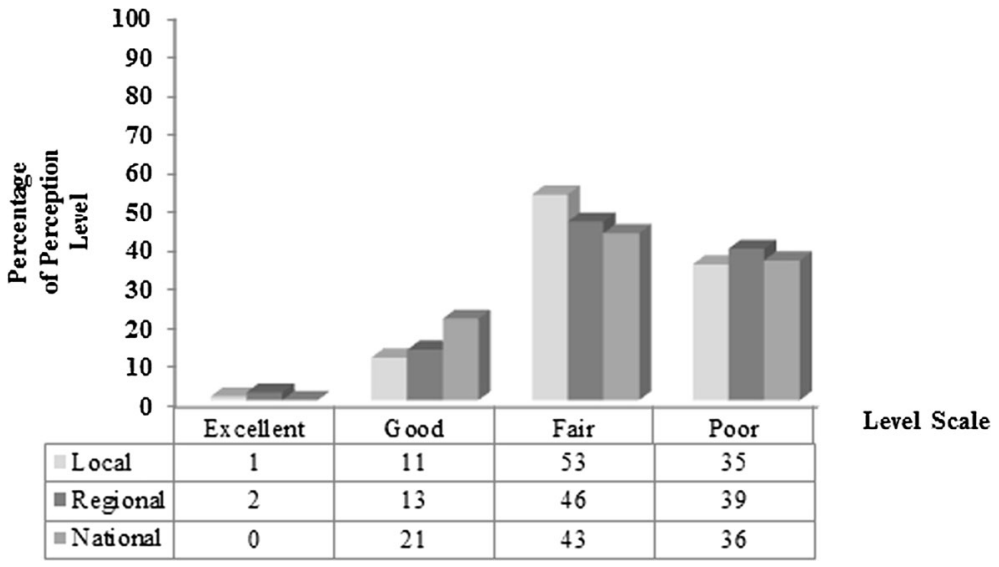

Fig. 6 Perception of flood risk management level of effectiveness of the different administrative levels of Chile by flooding unaffected residents

extreme event and commented on the low importance that this topic has in the political agenda.

On the other hand, residents, regardless of their experience with the floods, perceive that the resources are insufficient to address the problems of this risk in the city of Talcahuano. After the 2010 tsunami event, 47 and $41 \%$ of residents affected and unaffected by flooding events, respectively, felt that the government coping capacity is weak for managing flood episodes, especially extreme events (Fig. 7), and thus, effective improvements in this regard should be incorporated. Twenty-four per cent of affected residents and $23 \%$ of the unaffected residents perceive that the government has not developed a coping capacity approach to reduce flood risk. In this case, the beliefs of residents talk about changing the current reactive paradigm for a new, more proactive one with a focus on social needs, and based on social knowledge.

\subsection{Proposal of measures}

The technocratic vision of risk analysis and management has generated among people, in the words of Adams (1995), a "false sense of security", from the moment that their interpretations of the social and environmental dimensions have been neglected. If this

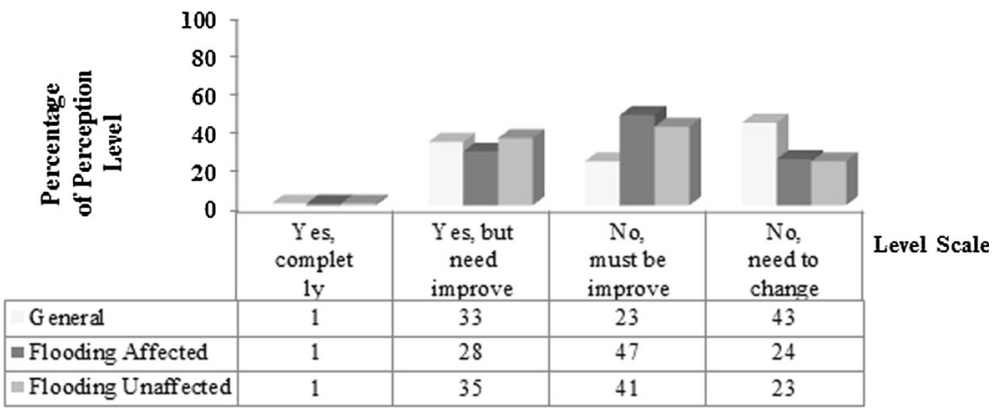

Fig. 7 Perceived capacity to cope with floods of citizens in flood-prone areas in Talcahuano 
misinterpretation continues, it could lead to erroneous results due to the omission of the social component, both in risk analysis processes and in developing and implementing actions to mitigate them. Therefore, knowing the views and solutions that the residents of risk exposure areas propose to reduce their vulnerability to risks might become a positive addition that would complement the technocratic work and could contribute to the efficiency and effectiveness of government actions. In addition, it might strengthen the link between people and their environment.

While Talcahuano residents perceived that flooding is a continuing risk to which they are exposed and whose management approach should be improved, respondents were asked to choose up to 5 options of those presented in Table 3, in relation to flood risk reduction. Residents affected by flooding events were more diverse in their choices compared with those who had had no experience with this risk (Fig. 8). The first group focused their response on 4 options, which scored between 83 and 90 preferences. These are: (1) forbidding development in flood areas (90); (2) retaining walls at sea boundary (90); (3) hydraulic work of sea boundary (protection) (88); (4) arranging adequate warning and evacuation systems (emergency planning) (83). These choices reflect an approach that aims to strike a balance between structural and non-structural measures, where the first still has greater acceptance among this type of resident.

Meanwhile, residents not affected by flooding prefer an approach to implement nonstructural measures, with social and environmental characteristics. These and their respective scores are: (1) forbidding development in flood areas (209); (2) arranging adequate warning and evacuation systems (emergency planning) (188); (3) retaining walls at sea boundary (165).

\subsection{Public involvement}

Knowing the level of social involvement in risk management allows us to have greater awareness of losses, impacts and disaster risk at local scale. It might also be helpful to build partnerships between local governments and other stakeholders, which would allow the negotiation of priorities, public investment and aid. Finally, it can facilitate the

Table 3 List of measures proposed to be implemented

\begin{tabular}{ll}
\hline Type of measures & \\
\hline A & Hydraulic work on sea boundary (protection) \\
\hline B & Stream channelization \\
C & Stream diversion \\
D & Dual network of rainwater/wastewater \\
E & Clean and maintenance fluvial beds \\
F & Forbidding development in flood areas \\
G & Arranging adequate warning and evacuation systems (emergency planning) \\
H & Educational campaigns \\
I & Arranging a right compensation system \\
J & Retaining walls at boundary sea \\
K & Others \\
\hline
\end{tabular}


implementation of measures which are aimed not only at reducing the risk of disasters, but also at providing additional benefits such as improved infrastructure, local services and integrated development.

The perception of participation of the residents in Talcahuano in regard to reducing flood risk in their city is very variable, considering the process of reconstruction planned for the new port city. This perception varied according to each respondent and did not present a clear trend among residents affected by flooding, unlike those who were unaffected (Fig. 9). For those who were unaffected, the concept of participation and involvement in local risk management to reduce disasters, especially those linked with some kind of flood, is tied to obtaining benefits (or not) as a victim. For the latter, the trend is clear, since $70 \%$ of them claimed that before or after the tsunami of 2010, they had had no impression of being involved in the local public policies designed to manage the risk and live with it.

On analysing the reasons for this, it can lead us to reflect on the existing centralism in the country, which prevents the solution of infrastructure problems that could easily be identified at the local and regional levels. This is due both to an atavistic centralizing tradition, and to the inability of some regions to have an entirely appropriate public administration to solve their problems. In Chile, these trends (micro-level) coexist and overlap with widespread social unrest (macro-level) that transcend the disaster experience, and are linked to the structural conditions of the Chilean model of development and its political system.

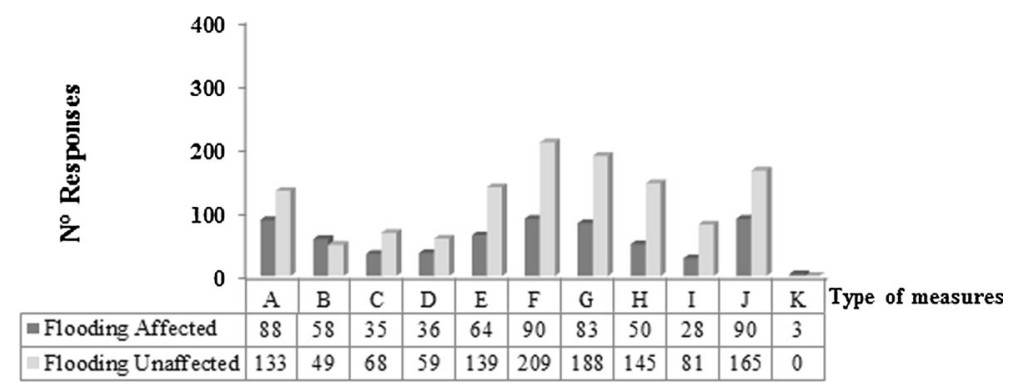

Fig. 8 Proposed measures to be implemented to improve the management of flood risk by citizens in floodprone areas in Talcahuano

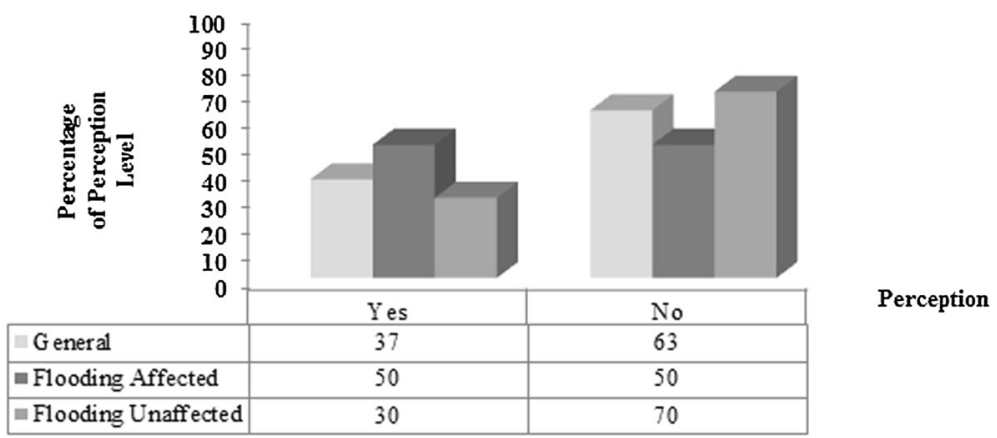

Fig. 9 Perception of participation in the management of flood risk by citizens in flood-prone areas in Talcahuano (in percentage) 


\section{Discussion}

Comparing these results on perception of flooding vulnerability with similar studies in Slovenia (Brilly and Polic 2005), the Netherlands (Terpstra and Gutteling 2008), Luxembourg (Schaich 2009) and Spain (Lara et al. 2010), some strong similarities and differences can be identified.

First, experience with risk appears to be a highly determining factor in the perception of the vulnerability of residents living in flood-prone areas. This is also indicated by studies conducted in the city of Celje (Slovenia) and some towns in the Costa Brava in Catalonia (Spain), whose residents suffered severe flooding events in 1990 and 1998 (in the case of Celje) and between 1994 and 2010 (in the case of the Costa Brava). However, experience with the phenomenon as a highly determining factor in the perception of vulnerability does not seem significant, even for permanent residents living in the areas exposed to flood risk, when there are flood risk management policies in the government agenda. This takes place because structural and non-structural mitigation measures are implemented, communication channels with the community are developed, and public participation is encouraged. Therefore, the residents of these flood-prone areas, which have suffered flooding events, feel safe and protected, thereby increasing their level of collective and individual security, not forgetting the reality in which they are embedded (perception of residents of the Netherlands). Unfortunately, these actions and behaviours were not present in the inhabitants of the city of Talcahuano.

Regarding the management and coping capacity perception assessment, one of the main problems is indicated by the negative evaluation of the capacity to deal with disasters at a local level. In particular, the actions implemented by the government are based on a lack of inclusion of residents in local development processes. Similar results are found in the research conducted in Costa Brava (Lara et al. 2010), Spain, and in Grand Forks, North Dakota, and East Grand Forks, Minnesota (Kweit and Keweit 2004) in the USA. In the latter case, the study found that cities tend to achieve better and greater recovery from the negative effects of a disaster when there is an interaction and involvement of their own human capital. This not only increased their resilience, but also contributed to the development of more effective coping capacity, in addition to a community that agreed with the actions and implemented measures to protect their lives.

Bakker et al. (2012) and Becker et al. (2007) argued that an appropriate institutional framework is essential for an efficient risk management. Taking the example of transboundary floods in the Rhine basin, we can see how the "Transboundary Flood Management in the Rhine basin: Challenges for Improved Cooperation project recommends several actions to improve cooperation between stakeholders. In particular, those aimed at reaching a common understanding of the problem and its analysis to develop an integrated view of the flood risk prevention strategies to be implemented in the future. In particular, an element that should be taken into account is that of time and future uncertainties associated with the potential effects of climate change.

When we observe the proposals of measures made by Talcahuano residents, it can be deduced that in this place, affected residents are more likely to support direct flood control approaches (Kahan et al. 2006), which were strongly validated in the 1980s. In this context, the construction of defence infrastructure exerts influence over connoted social perception of risk and contributes to a false sense of security in the community (Adams 1995; Slovic et al. 1982). That is an understandable response given the physical, social and 
environmental impact of the earthquake-tsunami of 27 February 2010. This, combined with their own fears, whose psychosocial effects, in this case, has not been treated.

Advances in technology, legislation and approaches to flood management indicate that the combination of structural and non-structural measures is the best way to confront the challenges of flood risks. The GEO-3 report in Johannesburg in 2002 emphasized that disaster mitigation should be focused on three global measures of appeasement: early warning measures, structural measures and spatial planning. These measures coincide with the goals of Hyogo Framework for Action, 2005-2015, and they have been seen in practice in the proposal of the Netherlands on multilevel safety approach.

However, in the development of this and other similar research papers, it seems that the simultaneous implementation of structural and non-structural measures is not an easy task. It depends greatly on the environmental risk awareness of the different stakeholders. For example, for the residents of Syr Valley (Luxembourg), the need to implement adaptation actions that conserve health and environmental benefits of flood-prone areas is a priority (Schaich, 2009). However, for the Scottish residents surveyed by Howgate and Kenyon (2009), the benefits produced by the flood management project become a crucial point in supporting such approach. Meanwhile, those affected by the phenomenon of erosion in the Malda district in India (Das, 2011) suggested the implementation of permanent measures, linked to structural action, to end the problem. In the East of England, for example, in order to preserve the environmental quality of coastal areas affected by flooding, it was necessary to implement conservationist measures agreed on by all the stakeholders, enabling local economic development and, at the same time, seeking a move towards environmental risk management (Milligan et al. 2009).

Finally, in relation to public involvement, the general acceptance of the concept of community risk management is based on the commitment of communities to obtain measures to mitigate consequences of flooding in the most effective and efficient manner. Individual and community involvement, as well as active commitment and concerted mitigation measures, has led to a wide variety of sustainable, effective and innovative solutions. Regarding the management of floods, this study is aimed at facilitating the inclusion of all those potentially affected by or interested in a decision, since those who are affected by a decision have the right to participate in the decision-making process.

The results show that the Chilean approach is not based on a "bottom-up" paradigm yet. Unlike Chile, this paradigm scheme has already been established in various parts of the World, such as in Canada, through HEROS (Home Emergency Response Organization System); in Coquitlam, British Columbia (Pearce 2003); in China with the Twinning Program (Levers and Bhatia 2011; UNISDR 2011); and in the Peruvian city of Chimbote (UN-HABITAT 2002). There are other important examples, such as Water Boards in the Netherlands, where, since the thirteenth century, there have been organizations based on the principle of volunteerism, which role within their jurisdiction is to take responsibility for water management and flood protection (Huisman 1997).

Therefore, for this case study, we postulate that residents must be invited and encouraged to participate in the formulation, design and implementation of local public policies that incorporate disaster risk reduction. This innovative management approach, in turn, requires significant changes with regard to social risk perception and attitudes towards natural hazards (which are becoming ever less natural), so that social learning processes can be activated. Hence, the need to change individual perception of risk through active channels for people participation, by realistically linking residents with the management of local development, might become a key issue to increase social learning and maintain 
awareness, as well as raising their risk culture. In addition, it can help to build public policies based on comprehensive, local, sustainable and cross-development.

\section{Conclusion}

Apart from the geophysical factors, the land use evolution in the city of Talcahuano has led to new territorial and environmental dynamics. Their effects exceed visual impact and affect the functioning of both natural and human environments. This process is facilitated by a strong local dynamism, based on public urban development in the context of a services, industry and construction-based economy. These factors have led to the creation of new at-risk territories.

We could assume that the results obtained in flood-prone areas in Talcahuano showed trends that can be transferred onto other coastal municipalities in the region of Biobío, or the coasts of Chile, but in any case, we should not generalize. Therefore, this is one of the first research papers based on social perception to include the effects of the 2010 earthquake-tsunami, which recorded unprecedented levels of social and environmental impact in Chile.

There are three main conclusions that can be highlighted from this study. First, the perception of vulnerability increases with experience. In other words, the feelings of the residents of being unsafe were directly linked to the experience of the episode on 27 February, which means the residents of Talcahuano were living with fear at the moment of data collection. This study has demonstrated that experience is an integral part of societal awareness, and influences the perception of Talcahuano society of risk. Nevertheless, experience is not the only a source of knowledge, but it should be considered as one of the most relevant.

The second conclusion links government management, coping capacity and resident proposals of measures for risk management. First, most of the residents of Talcahuano negatively evaluated the resources with which and ways in which the government managed the emergency cases. Improvement is the goal for the years to come. Although residents recognize that some actions have been implemented, they have questioned their effectiveness and complained that these actions had not been properly communicated to all stakeholders concerned. The resources are insufficient and inappropriate to manage and meet the challenges of the geographical exposure of the city and the vulnerability of its inhabitants. These contributed, in the case of residents affected by the flooding, to a sense of insecurity and a tendency towards structural measures as actions that led to protection. However, unaffected residents preferred non-structural measures coupled with environmental actions. This evidence strengthens the fact that the involvement of people will be crucial in achieving the paradigm, and to shift and evolve from flood control to flood management.

And the last, but by no means least, conclusion is regarding public participation in natural disaster management. From an integrative point of view, this research paper addressed — both theoretically and practically—-the involvement of residents in "the public affairs" and its relation to disaster management, specifically with flooding. From this we can conclude that most Talcahuano residents do not feel publicly involved, firstly, in local policy of disaster risk reduction, and, secondly, in the whole reconstruction process, especially in the case of unaffected residents. This lack of participation channels could have influenced the results of this study, because the local, regional and national 
management did not develop comprehensive and binding participatory processes. Rather, their participatory approaches were limited to the delivery of information and, sometimes, an enquiry. In this sense, it can be argued that the lack of local involvement in the management of natural hazards and the need to evolve towards an active participation of stakeholders is the product of a negative dualism: firstly, residents do not feel motivated or simply are uninterested in participating and, secondly, the local administrative bodies do not do enough to involve residents in the management of these risks.

This negative dualism is a major aspect to be modified. Active public participation in flood management in Talcahuano could allow for improvement in the management and modernization of public administration. In addition, it transforms social relations and promotes sustainable development. Finally, it would allow us to understand issues related to global risk by local application, facilitate communication flow, and it would contribute to the early detection of risks.

Open Access This article is distributed under the terms of the Creative Commons Attribution 4.0 International License (http://creativecommons.org/licenses/by/4.0/), which permits unrestricted use, distribution, and reproduction in any medium, provided you give appropriate credit to the original author(s) and the source, provide a link to the Creative Commons license, and indicate if changes were made.

\section{References}

Adams J (1995) Risk. University College Press, Londres

Alarcón F (1995) Evaluación de los riesgos naturales en el área metropolitana de Concepción, a través de la información del Diario El Sur. Universidad de Concepción, Memoria para optar al título de Licenciado en Educación, Concepción

Ashley RM, Blanskby J, Newman R, Gersonius B, Poole A, Lindley G, Smith S, Ogden S, Nowell R (2012) Learning and action alliances to build capacity for flood resilience. J Flood Risk Manag 5(1):14-22. doi:10.1111/j.1753-318X.2011.01108.X

Bahadur AV, Ibrahim M, Tanner T (2010) The resilience renaissance? Unpacking of resilience for tackling climate change and disasters. Institute of Development Studies (for the Strengthening Climate Resilience (SCR) consortium), Brighton, UK

Bakker R, Raab J, Milward H (2012) A preliminary theory of dark network resilience. J Policy Anal Manag 31(1):33-62. doi:10.1002/pam.20619

Becker G, Aerts J, Huitema D (2007) Transboundary flood management in the Rhine basin: challenges for improved cooperation. Water Sci Technol 56(4):125-135. doi:10.2166/wst.2007.544

Brilly M, Polic M (2005) Public perception of flood risks, flood forecasting and mitigation. Nat Hazards Earth Syst Sci 5:345-355. doi:10.5194/nhess-5-345-2005

Burch S, Sheppard SRJ, Shaw A, Flanders D (2010) Planning for climate change in a flood-prone community: municipal barriers to policy action and the use of visualizations as decision-support tools. J Flood Risk Manag 3(2):126-139. doi:10.1111/j.1753-318X.2010.01062.x

Carcellar N (2011) Addressing vulnerabilities through support mechanisms: HPFPI's ground experience in enabling the poor to implement community-rooted interventions on disaster response and risk reduction. Documento informativo elaborado para el Informe de evaluación global sobre la reducción del riesgo de desastres 2011. EIRD/ONU, Ginebra, Suiza

Das B (2011) Stakeholders' perception in identification of river bank erosion hazard: a case study. Nat Hazards 58(3):905-928. doi:10.1007/s11069-010-9698-z

González M (1997) Metodología de la investigación social. Aguaclara, Alicante

Howgate OR, Kenyon W (2009) Community cooperation with natural flood management: a case study in the Scottish Borders. Area 41(3):329-340. doi:10.1111/j.1475-4762.2008.00869.x

Huisman P (1997) La gestió de les inundacions als Països Baixos. Documents d'Anàlisis Geogràfica 31:31-57

Ilustre Municipalidad de Talcahuano (2006) Memoria Ejecutiva Plan Regulador Comunal de Talcahuano. SECPLAN, Talcahuano

Javeau C (1971) L'enquête par questionnaire: manuel a l'usage du praticien. Université de Bruxelles, Bruxelles 
Kahan J, Wu M, Hajiamiri S, Knopman D (2006) From flood control to integrated water resource management lessons for the gulf coast from flooding in other places in the last sixty years. Rand Publishing, Santa Monica, CA

Kweit MG, Keweit RW (2004) Citizen participation and citizen evaluation in disaster recovery. Am Rev Public Adm 34(4):354-373. doi:10.1177/0275074004268573

Lara A, Saurí D, Ribas A, Pavón D (2010) Social perceptions of floods and flood management in a Mediterranean area (Costa Brava, Spain). Nat Hazards Earth Syst Sci 10:2081-2091. doi:10.5194/ nhess-10-2081-2010

Levers J, Bhatia S (2011) Recovery as a catalyst for reducing risk. Documento informativo IRP elaborado para el Informe de evaluación global sobre la reducción del riesgo de desastres. EIRD/ONU, Ginebra, Suiza

Livengood A, Kunte K (2011) Participatory settlement mapping by Mahila Milan. Environ Urban. International Institute for Environment and Development 24(1):77-97. Recuperado el 01 de agosto de 2012, desde http://www.indiaenvironmentportal.org.in/files/file/participatory\%20planning\%20with\%20GIS. pdf

Lomas K, Giridharan R (2011) Thermal comfort standards, measured internal temperatures and thermal resilience to climate change of free-running buildings: a case-study of hospital wards. Build Environ 55:57-72. doi:10.1016/j.buildenv.2011.12.006

Mardones M, Rojas J (2012) Procesos de remoción en masa inducidos por el terremoto del 27F de 2010 en la franja costera de la Región del Biobío, Chile. Revista de geografía Norte Grande 53:57-74. doi:10. 4067/S0718-34022012000300004

Martin M (2010) Child participation in disaster risk reduction: the case of flood-affected children in Bangladesh. Third World Q 31(8):1357-1375. doi:10.1080/01436597.2010.541086

Maskrey A (1989) Disaster mitigation: a community based approach. Oxfam, Oxford, UK

Maskrey A (2011) Revisiting community-based disaster risk management. Environ Hazards 10(1):42-52. doi:10.3763/ehaz.2011.0005

Milligan J, O'Riordan T, Nicholson-Cole SA, Watkinson AR (2009) Nature conservation for future sustainable shorelines: lessons from seeking to involve the public. Land Use Policy 26(2):203-213. doi:10.1016/j.landusepol.2008.01.004

Mitchell T, Mechler R, Harris K (2012) Tackling exposure: placing disaster risk management at the Heart of National Economic and Fiscal Policy. Climate and Development Knowledge Network, London

Moreau K, Roumagnac A (2009) Feedback on flood risk management. In: 11th Plinius conference on Mediterranean storms

Norris F (2011) Behavioural science perspectives on resilience. CARRI Research Paper, 11, Community and Regional Resilience. Institute Oak Ridge, Tennessee, USA

ONEMI (2006) Informe consolidado sistema frontal 10 al 13 de julio de 2006. Recuperado 3 diciembre 2013, de http://repositoriodigitalonemi.cl/web/handle/123456789/391

ONEMI (2008) Informe consolidado sistema frontal 24 de agosto al 01 de septiembre Recuperado 3 diciembre 2013, de http://repositoriodigitalonemi.cl/web/handle/2012/401

ONEMI (2012) Informe técnico actualizado 27 de mayo 2010, Terremoto Cauquenes 27 febrero 2010. Recuperado 3 diciembre 2013, de http://repositoriodigitalonemi.cl/web/handle/2012/468

Pearce L (2003) Disaster management and community planning, and public participation: how to achieve sustainable hazard mitigation. Nat Hazards 28:221-228. doi:10.1023/A:1022917721797

Pérez G (2001) Investigación cualitativa. Retos e interrogantes: I Métodos, $3^{\mathrm{a}}$ edn. La Muralla, Madrid

Perwais A (2011) People-centered approach in integrated flood risk management in the lower Mekong basin. Flood Management and Mitigation Program (FMMP). C4: Flood Emergency Management Strengthening. APFM. Recuperado el 17 de agosto de 2011, desde http://www.apfm.info/pdf/HelpDesk_ meeting/ADPC.pdf

Prasad K (2005) Community approaches to flood management in India, APFM. Recuperado el 14 de febrero de 2008, desde http://www.apfm.info/pdf/pilot_projects/manual_india.pdf

Ribarova I, Assimacopoulos D, Jeffrey P, Daniell KA, Inman D, Vamvakeridou-Lyroudia LS, Melin T, Kalinkov P, Ferrand N, Tarnaki K (2011) Research-supported participatory planning for water stress mitigation. J Environ Planning Manage 54(2):283-300. doi:10.1080/09640568.2010.506074

Rubin C (1991) Recovery from disaster. In: Drabek TE, Hoetmer GJ (eds) Emergency management: principles and practices for local government. International City, Washington, DC, pp 224-261

Samuels PG, Bramley ME \& Evans EP (2010) Reducing Uncertainty in Conveyance Estimation. In: Flood Risk management, short course. UNESCO- IHE, The Netherlands 2010. Recuperado el 15 de junio de 2010 desde ftp://ftp.hrwallingford.co.uk/pub/River_conveyance/paper.pdf 
Satterthwaite D (2011) What role for low-income communities in urban areas in disaster risk reduction? Documento informativo elaborado para el Informe de evaluación global sobre la reducción del riesgo de desastres 2011. EIRD/ONU, Ginebra, Suiza

Schaich H (2009) Local residents' perceptions of floodplain restoration measures in Luxembourg's Syr Valley. Landsc Urban Plan 93(1):20-30. doi:10.1016/j.landurbplan.2009.05.020

Sierra R (1985) Técnicas de investigación social. Parainfo, Madrid

Sierra R (2001) Técnicas de investigación social: teoría y ejercicios, 14a edn. Paraninfo Thomson Learning, Madrid

Slovic P, Fischhoff B, Lichtenstein S (1982) Why study risk perception? Risk Anal 2(2):83-93

Sok S, Lebel L, Bastakoti R, Thau S, Samath S (2011) Role of villagers in building community resilience through disaster risk management: a case study of a flood-prone village on the banks of the Mekong River in Cambodia. In: Stewart M, Coclanis P (eds) Environmental change and agricultural sustainability in the mekong delta, 45(3):241-255). Springer, Dordrecht. doi: 10.1007/978-94-007-0934-8_14

Tanahashi G (2005) Niigata's disaster information at the flood of 13 July, 2004. In: Organizing community participation: APFM. Technical Document, Flood management policy series. Associated Programme on Flood Management, World Meteorological Organization, Geneva

Terpstra T, Gutteling JM (2008) Households' perceived responsibilities in flood risk management in the Netherlands. Int J Water Resour 24(4):555-565. doi:10.1080/07900620801923385

United Nations International Strategy for Disaster Reduction (UNISDR) (2011) Assessment report on disaster risk reduction. Revealing risk, redefining development. UNISDR, Geneva, Switzerland

United Nations/HABITAT (2002) Manual N 2 Gestión comunitaria de riesgos. Foro ciudades para la vida. UN-HABITAT, Lima, Perú

Visauta B (1989) Técnicas de investigación social I: Recogida de datos. Promociones y Publicaciones Universitarias, Barcelona

White I, Kingston R, Barker A (2010) Participatory GIS for developing flood risk management policy options. J Flood Risk Manag 3(4):337-346. doi:10.1111/j.1753-318X.2010.01083.x

World Meteorological Organization (WMO) (2008) Organizing community participation. Technical document, flood management policy series. Associated Programme on Flood Management (APFM), Geneva 